Article

\title{
Micro-Structures and High-Temperature Friction-Wear Performances of Laser Cladded Cr-Ni Coatings
}

\author{
Li Jiahong ${ }^{1}$ (D) and Kong Dejun ${ }^{1,2, *}$ \\ 1 College of Mechanical Engineering, Changzhou University, Changzhou 213164, China; \\ lijiahonglyh@163.com \\ 2 Changzhou High Technology Research Key Laboratory of Mould Advanced Manufacturing, \\ Changzhou University, Changzhou 213164, China \\ * Correspondence: kong-dejun@163.com; Tel.: +86-0519-8116-9810
}

Received: 2 December 2017; Published: 15 January 2018

\begin{abstract}
Cr}-\mathrm{Ni}$ coatings with the mass ratios of $17 \% \mathrm{Cr}-83 \% \mathrm{Ni}, 20 \% \mathrm{Cr}-80 \% \mathrm{Ni}$ and $24 \% \mathrm{Cr}-76 \%$ $\mathrm{Ni}$ were fabricated on $\mathrm{H} 13$ hot work mould steel using a laser cladding (LC). The surface-interface morphologies, chemical elements, surface roughness and phase composition of the obtained $\mathrm{Cr}-\mathrm{Ni}$ coatings were analysed using a scanning electron microscope (SEM), energy disperse spectroscopy (EDS), atomic force microscope (AFM) and X-ray diffractometer (XRD), respectively. The friction-wear properties and wear rates of $\mathrm{Cr}-\mathrm{Ni}$ coatings with the different mass ratios of $\mathrm{Cr}$ and $\mathrm{Ni}$ at $600{ }^{\circ} \mathrm{C}$ were investigated, and the worn morphologies and wear mechanism of $\mathrm{Cr}-\mathrm{Ni}$ coatings were analysed. The results show that the phases of $\mathrm{Cr}-\mathrm{Ni}$ coatings with mass ratios of $17 \% \mathrm{Cr}-83 \% \mathrm{Ni}, 20 \% \mathrm{Cr}-80 \% \mathrm{Ni}$ and $24 \% \mathrm{Cr}-76 \% \mathrm{Ni}$ are composed of $\mathrm{Cr}+\mathrm{Ni}$ single-phases and their compounds at the different stoichiometry, the porosities on the $\mathrm{Cr}-\mathrm{Ni}$ coatings increase with the $\mathrm{Cr}$ content increasing. The average coefficient of friction (COF) of $17 \% \mathrm{Cr}-83 \% \mathrm{Ni}, 20 \% \mathrm{Cr}-80 \%$ $\mathrm{Ni}$ and $24 \% \mathrm{Cr}-76 \%$ coatings are 1.10, 0.33 and 0.87 , respectively, in which the average COF of $20 \% \mathrm{Cr}-80 \% \mathrm{Ni}$ coating is the lowest, exhibiting the better anti-friction performance. The wear rate of $17 \% \mathrm{Cr}-83 \% \mathrm{Ni}, 20 \% \mathrm{Cr}-80 \% \mathrm{Ni}$ and $24 \% \mathrm{Cr}-76 \% \mathrm{Ni}$ coatings is $4.533 \times 10^{-6}, 5.433 \times 10^{-6}$, and $1.761 \times 10^{-6} \mathrm{~N}^{-1} \cdot \mathrm{s}^{-1}$, respectively, showing the wear resistance of $\mathrm{Cr}-\mathrm{Ni}$ coatings at a high temperature increases with the $\mathrm{Cr}$ content, in which the wear rate is $24 \% \mathrm{Cr}-76 \% \mathrm{Ni}$ coating with the better reducing wear. The wear mechanism of $17 \% \mathrm{Cr}-83 \% \mathrm{Ni}$ and $20 \% \mathrm{Cr}-80 \% \mathrm{Ni}$ and $24 \% \mathrm{Cr}-76 \%$ coatings at $600{ }^{\circ} \mathrm{C}$ is primarily adhesive wear, and that of $24 \% \mathrm{Cr}-76 \%$ coating is also accompanied by oxidative wear.
\end{abstract}

Keywords: $\mathrm{Cr}-\mathrm{Ni}$ coating; laser cladding (LC); coefficient of friction (COF); high temperature wear; wear mechanism

\section{Introduction}

As a hot work mould steel, $\mathrm{H} 13$ steel (4Cr5MoSiV1) with high wear resistance, thermal stability and fatigue resistance, etc. [1] is widely used on hot forging, hot extrusion and hot casting mould manufacturing [2], of which comprehensive mechanical properties are well at medium temperature of $\sim 550{ }^{\circ} \mathrm{C}$ [3]. The microstructure of $\mathrm{H} 13$ steel at high temperature of $\geq 550{ }^{\circ} \mathrm{C}$ is changed constantly; its hardness declines rapidly, which affects its wear properties [2,4]. At the same time, the mould surface will have wear failure, thermal fatigue cracking and other failures [1], due to strong friction and mechanical impact at high temperature [2]. Thermal spraying with high efficiency, low cost and easy controlling is often used to improve the mould wear resistance [5,6], but it has some defects such as low material utilization, large waste and low bonding strength, etc. As an advanced surface 
technology, the laser cladded coatings are metallurgically bonded with the substrate after alloy powder rapid melting and solidification [2], which is suitable for a variety of moulds. The LC has several outstanding advantages in the surface modification field such as refined microstructures, metallurgical bonding and narrow heat affected zone (HAZ) [7,8], etc. Laser cladding improves the bonding strength between the coating and the substrate comparing to thermal spraying and reduces the loss of the coating during wear [9]. Coatings can greatly improve the wear resistance of the surface of the material to improve its wear properties [10,11], particularly compared to the substrate [12]. The composition of $\mathrm{Ni}$ and $\mathrm{Cr}$ affects the wear resistance of $\mathrm{Cr}-\mathrm{Ni}$ coating $[13,14]$; research on the $\mathrm{Cr}-\mathrm{Ni}$ coating is mainly concentrated on its anti-oxidation. Bala et al. [15] investigated the oxidation behaviour of $\mathrm{Ni}-20 \mathrm{Cr}$ and $\mathrm{Ni}-50 \mathrm{Cr}$ coatings in the cycle of heating and cooling conditions. Zhang et al. [16] analysed the oxidation resistance of $\mathrm{Ni}-\mathrm{Cr}$ nano-composite films at high temperature. The above $\mathrm{Cr}-\mathrm{Ni}$ coatings were fabricated using an electro-deposition; there were few reports on the friction-wear properties of laser cladded $\mathrm{Cr}-\mathrm{Ni}$ coatings with the different mass ratios of $\mathrm{Cr}$ and $\mathrm{Ni}$ at high temperature. In this study, the $\mathrm{Ni}-\mathrm{Cr}$ coatings with the mass ratios of $17 \% \mathrm{Cr}-83 \% \mathrm{Ni}, 20 \% \mathrm{Cr}-80 \% \mathrm{Ni}$ and $24 \% \mathrm{Cr}-76 \%$ Ni were fabricated using an LC on H13 hot work mould steel. The morphologies, chemical elements, phases and surface roughness of the obtained $\mathrm{Cr}-\mathrm{Ni}$ coatings were analysed using a scanning electronic microscopy (SEM), energy disperse spectroscopy (EDS), X-ray diffractometer (XRD) and atomic force microscopy (AFM), respectively. The effects of mass ratios of $\mathrm{Cr}$ and $\mathrm{Ni}$ on high temperature friction-wear performances of laser-cladded $\mathrm{Cr}-\mathrm{Ni}$ coating were discussed, and the mechanism of $\mathrm{Cr}-\mathrm{Ni}$ coating also analysed, which provided an experimental basis for the surface modification of H13 hot work mould steel.

\section{Experiment}

The substrate was $\mathrm{H} 13$ hot work mould steel; its chemical composition is shown in Table 1. Three kinds of powders were differentiated by mass ratios of $\mathrm{Cr}$ and $\mathrm{Ni}$ as follows: $17 \% \mathrm{Cr}-83 \% \mathrm{Ni}$, $20 \% \mathrm{Cr}-80 \% \mathrm{Ni}$ and $24 \% \mathrm{Cr}-76 \% \mathrm{Ni}$. The morphologies and chemical compositions of $\mathrm{Cr}-\mathrm{Ni}$ powders were analysed using an JSM-6360LA type SEM (NEC Electronics Corporation, Tokyo, Japan) and its configured EDS, respectively, and the phase compositions of $\mathrm{Cr}-\mathrm{Ni}$ powders were analysed using a D/max 2500PC type XRD (Rigaku Corporation, Tokyo, Japan).

Table 1. Chemical composition of $\mathrm{H} 13$ hot work mould steel/wt \%.

\begin{tabular}{ccccccccc}
\hline $\mathbf{C}$ & $\mathbf{S i}$ & $\mathbf{M n}$ & $\mathbf{C r}$ & $\mathbf{M o}$ & $\mathbf{V}$ & $\mathbf{P}$ & $\mathbf{S}$ & $\mathbf{F e}$ \\
\hline $0.32-0.45$ & $0.80-1.20$ & $0.20-0.50$ & $4.75-5.50$ & $1.10-1.75$ & $0.80-1.20$ & $\leq 0.03$ & $\leq 0.03$ & other \\
\hline
\end{tabular}

The above three kinds of $\mathrm{Cr}-\mathrm{Ni}$ powders were respectively covered on $\mathrm{H} 13$ steel with the thickness of $2 \mathrm{~mm}$, the acetone solution was dropped on the surfaces of $\mathrm{Cr}-\mathrm{Ni}$ powders using a dropper. After drying at room temperature for $5 \mathrm{~h}$, the LC test was carried out on a ZKSX-2008 type fiber-coupled of laser spraying system (Jiangsu Zhongke Sixiang Laser Technology Co., Ltd., Danyang, China), the technological parameters were: focal length of laser beam is $400 \mathrm{~mm}$, laser power of $1400 \mathrm{~W}$, spot diameter of $4 \mathrm{~mm}$, moving speed of $10 \mathrm{~m} / \mathrm{s}$, Argon was used as the shielding gas during the LC test. After the LC test, the surface-interface morphologies and chemical compositions of the obtained $\mathrm{Cr}-\mathrm{Ni}$ coatings were analysed using a JSM-6360LA type SEM and its configured EDS, the surface roughness was analysed using a CSPM5500 type AFM (Original Nanoscale Instrument Co., Ltd., Beijing, China), and the phase compositions of $\mathrm{Cr}-\mathrm{Ni}$ coatings were analysed using a $\mathrm{D} / \max 2500 \mathrm{PC}$ type XRD. The microhardness of the coatings was measured using a HMV-2T type Vickers microhardness tester (SHIMADZU enterprise management (China) Co., Ltd., Shanghai, China) with the load of $2 \mathrm{~N}$ and the loading time of $10 \mathrm{~s}$. The friction and wear test were conducted on a HT-1000 type high temperature friction-wear tester (Lanzhou Zhongke Kaihua Science and Technology Development Co., Ltd., Lanzhou, China) at $600{ }^{\circ} \mathrm{C}$. The wear test parameters: friction method of 
sliding friction, motor frequency of $8.93 \mathrm{~Hz}$, friction-pair of ceramic ball with the diameter of $3 \mathrm{~mm}$ load of $5 \mathrm{~N}$, speed of $500 \mathrm{rpm}$, rotation radius of $4 \mathrm{~mm}$, duration time of $30 \mathrm{~min}$. After the wear test, the profiles of worn tracks were analysed using a VHX-700FC type super-depth three-dimensional microscopic system (Keyence Corporation, Osaka, Japan), and the morphologies and energy spectrum of worn tracks were analysed using a SEM and its configured d EDS, respectively.

\section{Analysis and Discussion}

\subsection{Morphologies, EDS and XRD Analysis of Cr-Ni Powder}

The morphologies of $17 \% \mathrm{Cr}-83 \% \mathrm{Ni}$ and $20 \% \mathrm{Cr}-80 \% \mathrm{Ni}$ and $24 \% \mathrm{Cr}-76 \% \mathrm{Ni}$ powders are shown in Figure 1a-c. Their shapes were basically similar, indicating that the mass ratios of $\mathrm{Cr}$ and $\mathrm{Ni}$ had no obvious effects on the powder morphologies. The point of 001 was $\mathrm{Cr}$ powder, whose surface was smooth and had lines, the result of EDS analysis is shown in Figure 1d. The point of 002 was Ni powder, whose surface was pine-cone-shaped, the result of EDS analysis is shown in Figure 1e. From the above analyses, it can be seen that the $\mathrm{Cr}-\mathrm{Ni}$ powder was composed of pure $\mathrm{Cr}$ and $\mathrm{Ni}$ powders, without other impurities.

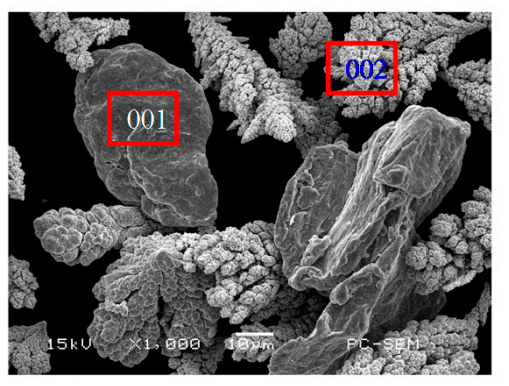

(a)

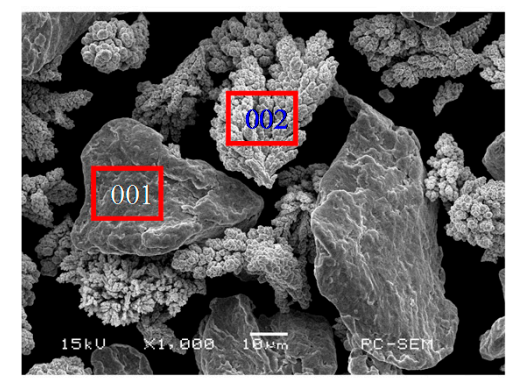

(b)

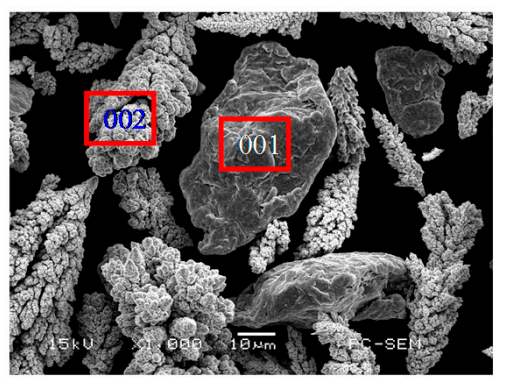

(c)

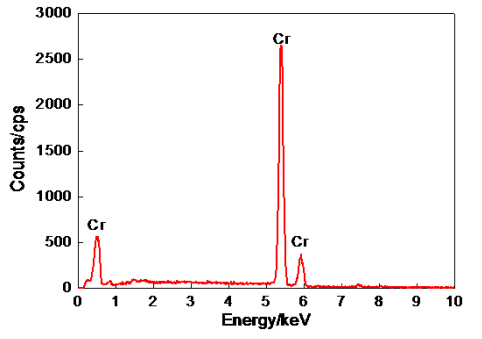

(d)



(e)

Figure 1. Morphologies and EDS analysis of $\mathrm{Cr}-\mathrm{Ni}$ powders with different mass ratios of $\mathrm{Cr}$ and Ni. (a) Morphology of $17 \% \mathrm{Cr}-83 \% \mathrm{Ni}$ powder; (b) Morphology of $20 \% \mathrm{Cr}-80 \% \mathrm{Ni}$ powder; (c) Morphology of $24 \% \mathrm{Cr}-76 \% \mathrm{Ni}$ powder; (d) EDS analysis at 001 point; (e) EDS analysis at 002point.

The XRD patterns of $\mathrm{Cr}-\mathrm{Ni}$ powders with different mass ratios of $\mathrm{Cr}$ and $\mathrm{Ni}$ are shown in Figure 2a-c. There were no obvious differences at the XRD diffraction peaks, indicating that the $\mathrm{Cr}-\mathrm{Ni}$ powders with different ratios of $\mathrm{Cr}$ and $\mathrm{Ni}$ were all composed of $\mathrm{Cr}$ and $\mathrm{Ni}$ phases. 


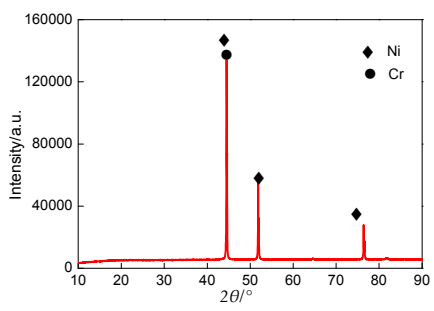

(a)

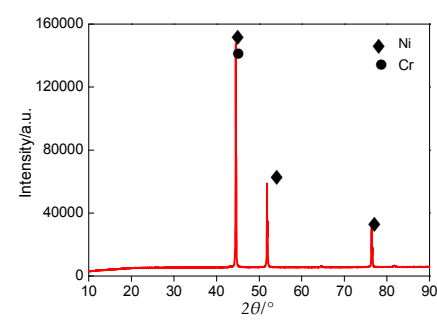

(b)

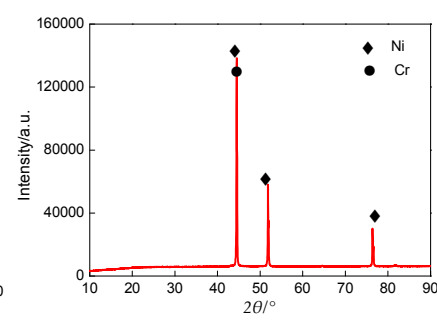

(c)

Figure 2. XRD patterns of $\mathrm{Cr}-\mathrm{Ni}$ powders with different mass ratios of $\mathrm{Cr}$ and Ni. (a) XRD patterns of $17 \%$ Cr- $83 \%$ Ni powder; (b) XRD patterns of $20 \%$ Cr- $80 \%$ Ni powder; (c) XRD patterns of $24 \%$ Cr- $76 \%$ Ni powder.

\subsection{Morphologies of $\mathrm{Cr}-\mathrm{Ni}$ Coating Surface}

Figure 3a shows the morphology of $17 \% \mathrm{Cr}-83 \% \mathrm{Ni}$ coating surface, which was relatively smooth with fine porosities and no obvious defects. The plane scan analysis result of $17 \% \mathrm{Cr}-83 \% \mathrm{Ni}$ coating is shown in Figure 3b, indicating that the $17 \% \mathrm{Cr}-83 \% \mathrm{Ni}$ coating was composed of $\mathrm{Cr}$ and $\mathrm{Ni}$, with no other elements. The $\mathrm{Cr}$ and Ni were uniformly distributed, as shown in Figure 3c,d.

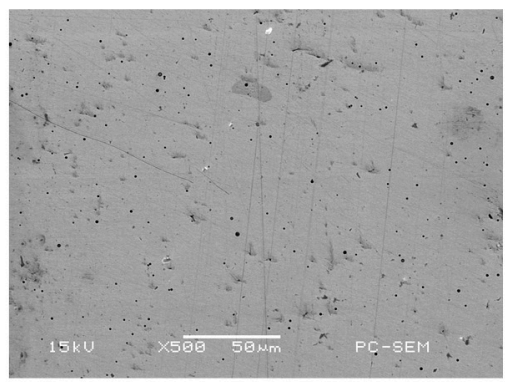

(a)

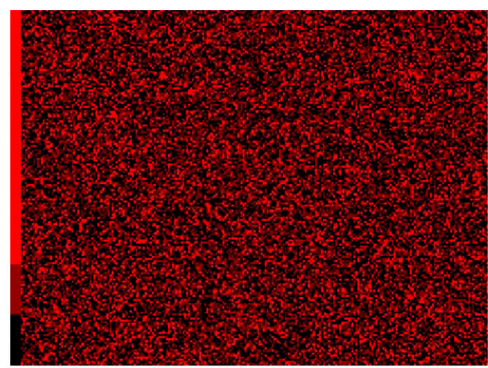

(c)

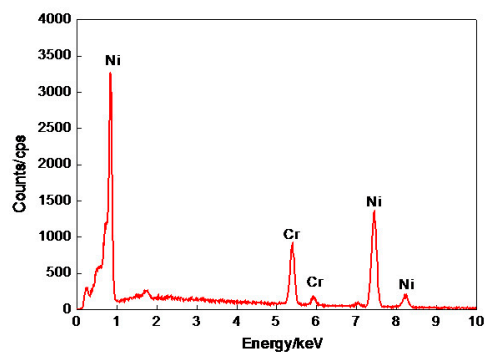

(b)

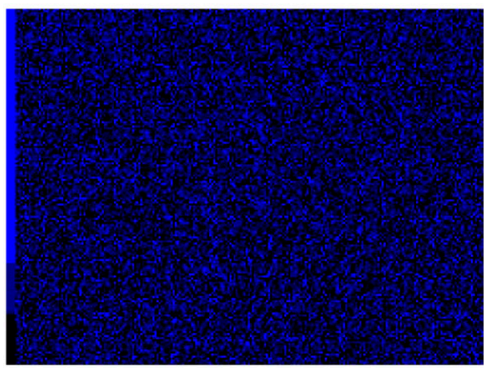

(d)

Figure 3. Plane scan analysis of $17 \% \mathrm{Cr}-83 \% \mathrm{Ni}$ coating surface. (a) Plane scanned position; (b) Plane scan analysis $17 \%$ Cr-83\% Ni coating; (c) Distribution of Cr content; (d) Distribution of Ni content.

The morphology of $20 \% \mathrm{Cr}-80 \% \mathrm{Ni}$ coating surface is shown in Figure $4 \mathrm{a}$, which was similar to that in Figure 3a, but a few porosities were larger. The plane scan analysis result of $20 \% \mathrm{Cr}-80 \% \mathrm{Ni}$ coating is shown in Figure $4 \mathrm{~b}$, indicating that the $20 \% \mathrm{Cr}-80 \% \mathrm{Ni}$ coating was composed of $\mathrm{Cr}$ and $\mathrm{Ni}$, with no other elements. The distributions of $\mathrm{Cr}$ and $\mathrm{Ni}$ are shown in Figure $4 \mathrm{c}$, d, with no obvious atom-poor zones. 


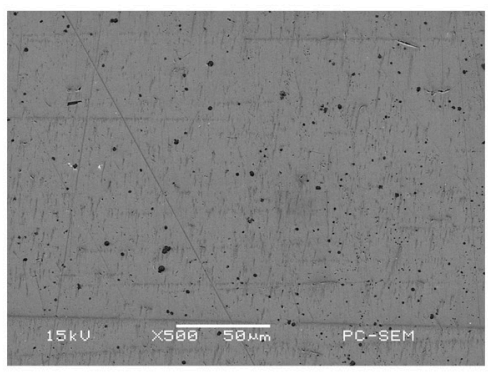

(a)

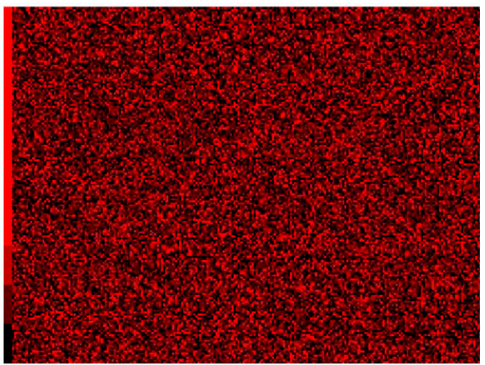

(c)

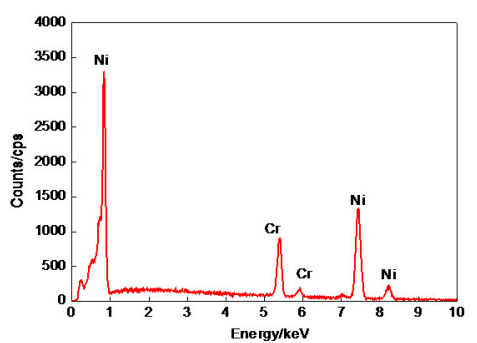

(b)

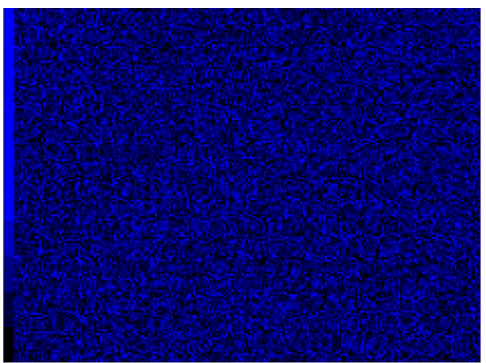

(d)

Figure 4. Plane scan analysis of $20 \% \mathrm{Cr}-80 \% \mathrm{Ni}$ coating surface. (a) Plane scanned position; (b) Plane scan analysis 20\% Cr-80\% Ni coating; (c) Distribution of Cr content; (d) Distribution of Ni content.

The morphology of $24 \% \mathrm{Cr}-76 \% \mathrm{Ni}$ coating surface is shown in Figure 5a. Compared with Figures $3 \mathrm{a}$ and $4 \mathrm{a}$, the porosity sizes became larger. The plane scan analysis result of $24 \% \mathrm{Cr}-76 \% \mathrm{Ni}$ coating is shown in Figure 5b, indicating that the $24 \% \mathrm{Cr}-76 \% \mathrm{Ni}$ coating was also composed of $\mathrm{Cr}$ and $\mathrm{Ni}$, with no other impurity elements. The distributions of $\mathrm{Cr}$ and $\mathrm{Ni}$ are shown in Figure $5 \mathrm{c}, \mathrm{d}$, which are the same as those of $17 \% \mathrm{Cr}-83 \% \mathrm{Ni}$ and $20 \% \mathrm{Cr}-80 \%$ Ni coatings, with no evident difference. Comparing the morphologies of surfaces in Figures 3,4 and 5a, the porosities became larger, which were related to the $\mathrm{Cr}$ content. The forming of porosities was because of the presence of an eddy flux, forward and downward, around the key hole interface; the formed bubbles do not escape from the molten pool, but remain entrapped, thus generating porosity at the end of the solidification process [17-19], and another reason for porosity generation was that the free carbons in the powders were easily combined with the $\mathrm{O}$ in the air to form $\mathrm{CO}$ or $\mathrm{CO}_{2}[19]$.

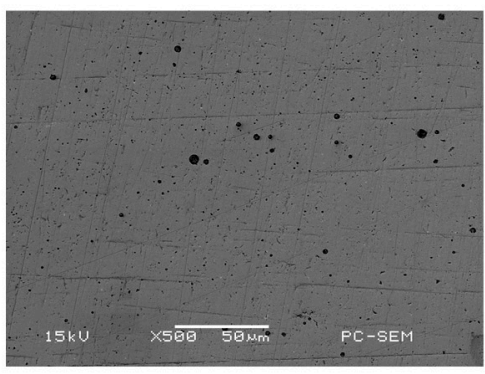

(a)

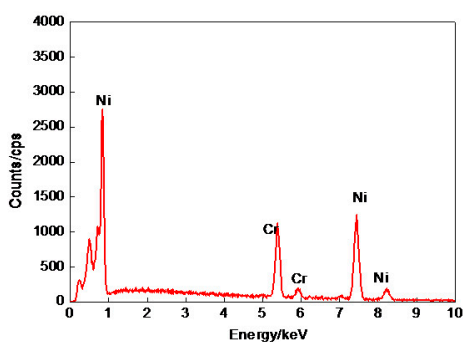

(b)

Figure 5. Cont. 


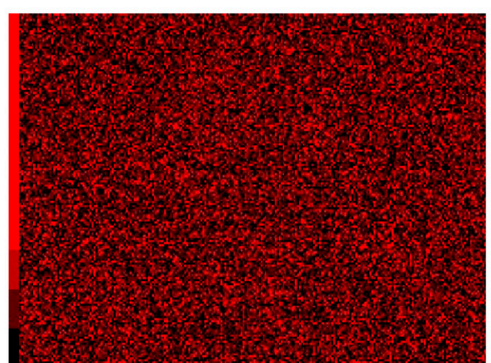

(c)

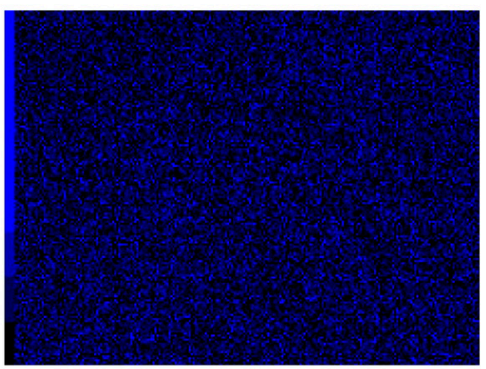

(d)

Figure 5. Plane scan analysis of $24 \% \mathrm{Cr}-76 \% \mathrm{Ni}$ coating surface. (a) Plane scanned position; (b) Plane scan analysis $24 \% \mathrm{Cr}-76 \% \mathrm{Ni}$ coating; (c) Distribution of Cr content; (d) Distribution of Ni content.

\subsection{Line Scan Analysis of $\mathrm{Cr}-\mathrm{Ni}$ Coating Surface}

The line scan analyses of $17 \% \mathrm{Cr}-83 \%, 20 \% \mathrm{Cr}-80 \% \mathrm{Ni}$ and $24 \% \mathrm{Cr}-76 \% \mathrm{Ni}$ coating interfaces are shown in Figures $6-8$. The $\mathrm{Cr}$ content of $17 \% \mathrm{Cr}-83 \% \mathrm{Ni}$ coating was higher than that of the substrate, as shown in Figure $6 \mathrm{a}$. The $\mathrm{Ni}$ of $17 \% \mathrm{Cr}-83 \% \mathrm{Ni}$ coating maintained high content, while that of substrate maintained low content; the metallurgical bonding layer was formed at the coating-substrate interface, as shown in Figure $6 \mathrm{~b}$. The Fe content was high in the substrate, and declined at the diffusion layer, as shown in Figure 6c.

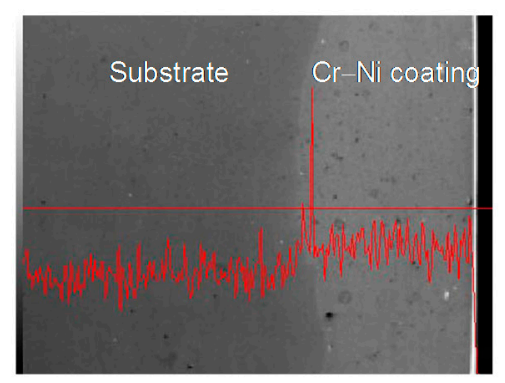

(a)

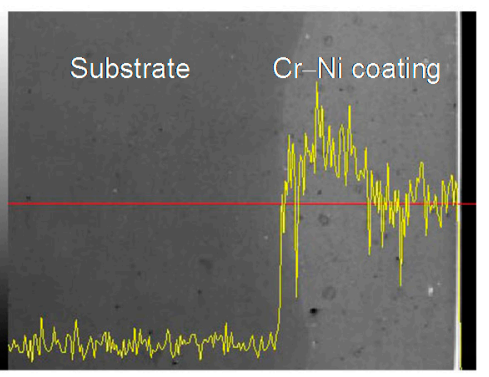

(b)

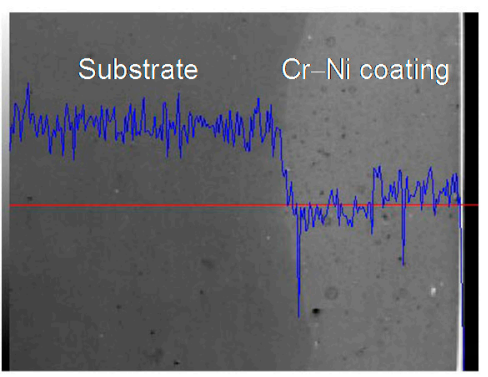

(c)

Figure 6. Line scan analysis of $17 \% \mathrm{Cr}-83 \% \mathrm{Ni}$ coating interface. (a) Line scan analysis of $\mathrm{Cr}$ content; (b) Line scan analysis of Ni content; (c) Line scan analysis of Fe content.

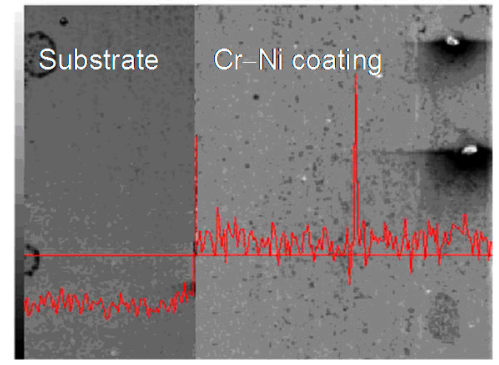

(a)

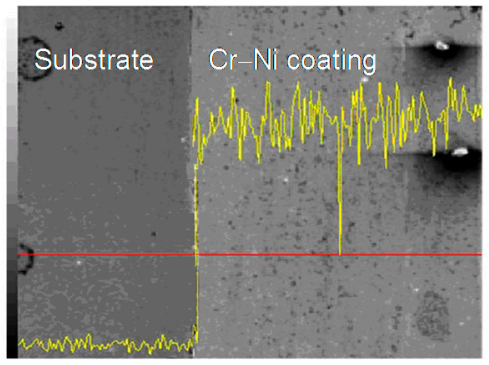

(b)

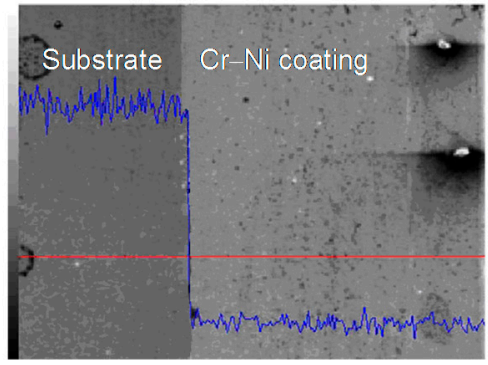

(c)

Figure 7. Line scan analysis of $20 \% \mathrm{Cr}-80 \% \mathrm{Ni}$ coating interface. (a) Line scan analysis of $\mathrm{Cr}$ content; (b) Line scan analysis of Ni content; (c) Line scan analysis of Fe content. 


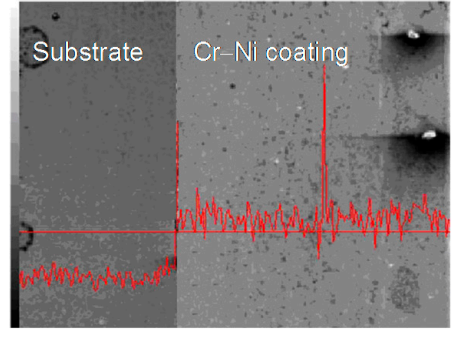

(a)

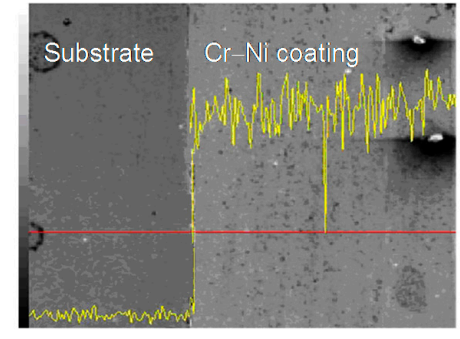

(b)

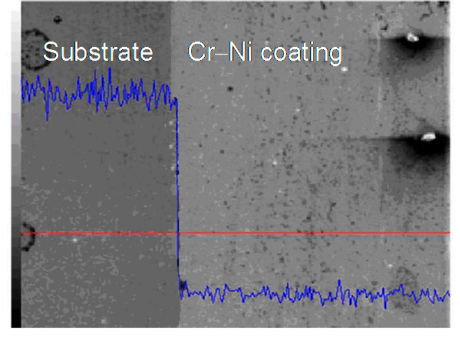

(c)

Figure 8. Line scan analysis of $24 \% \mathrm{Cr}-76 \% \mathrm{Ni}$ coating interface. (a) Line scan analysis of $\mathrm{Cr}$ content; (b) Line scan analysis of Ni content; (c) Line scan analysis of Fe content.

The line scan analysis of $20 \% \mathrm{Cr}-80 \% \mathrm{Ni}$ coating interface is shown in Figure 7 . The $\mathrm{Cr}$ content of $20 \% \mathrm{Cr}-80 \% \mathrm{Ni}$ coating increased slightly compared with that of the substrate, as shown in Figure 7a. The Ni maintained low content in the substrate, and increased to a high value at the metallurgical bonding layer of $20 \% \mathrm{Cr}-80 \% \mathrm{Ni}$ coating, as shown in Figure $7 \mathrm{~b}$. The Fe content of the substrate was far higher than that of $20 \% \mathrm{Cr}-80 \% \mathrm{Ni}$ coating, and dropped to a small value at the diffusion layer, as shown in Figure 7c.

The line scan analysis of $24 \% \mathrm{Cr}-76 \% \mathrm{Ni}$ coating interface is shown in Figure 8 . The Cr contents of $24 \% \mathrm{Cr}-76 \% \mathrm{Ni}$ coating and the substrate changed significantly, which decreased rapidly at the diffusion layer, as shown in Figure 8a. The Ni maintained a lower content in the substrate, and increased to a high value at the metallurgical bonding layer of $20 \% \mathrm{Cr}-80 \%$ Ni coating, as shown in Figure $8 \mathrm{~b}$. On the contrary, Fe had a higher content in the substrate and decreased at the diffusion layer, as shown in Figure 8c.

From the above line scan analyses, it can be known that the $\mathrm{Cr}$ and $\mathrm{Ni}$ formed the atom-rich zones in the three kinds of $\mathrm{Cr}-\mathrm{Ni}$ coatings and the diffusion layer at the coating-substrate interface, indicating that the metallurgical bonding was produced between the coating and the substrate after LC.

\subsection{AFM Analysis of $\mathrm{Cr}-\mathrm{Ni}$ Coating Surface}

The topographies of three kinds of $\mathrm{Cr}-\mathrm{Ni}$ coatings were measured using an AFM, as shown in Figure $9 \mathrm{a}-\mathrm{c}$. The image size was $50,000 \mathrm{~nm} \times 50,000 \mathrm{~nm}$. The parameters such as contour arithmetic mean deviation of $S_{\mathrm{a}}$, surface morphology root mean square deviation of $S_{\mathrm{q}}$, surface height distribution inclination $S_{\mathrm{sk}}$, surface height distribution kurtosis $S_{\mathrm{ku}}$ and surface ten-point height $S_{\mathrm{z}}$ were used to characterize the three-dimensional micro-topography; their values are shown in Table 2. There were no significant differences in the surface roughness of $\mathrm{Cr}-\mathrm{Ni}$ coatings; the effect on the friction-wear properties was negligible due to their small magnitude grade.

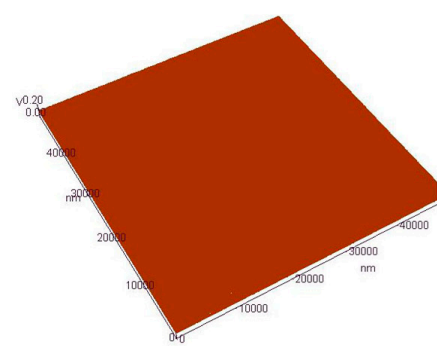

(a)

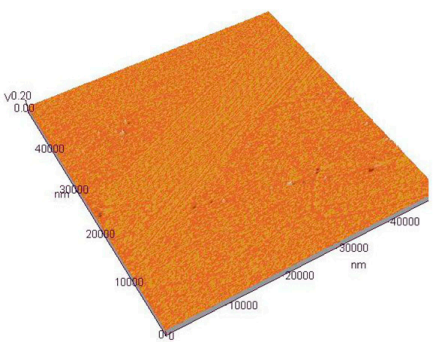

(b)

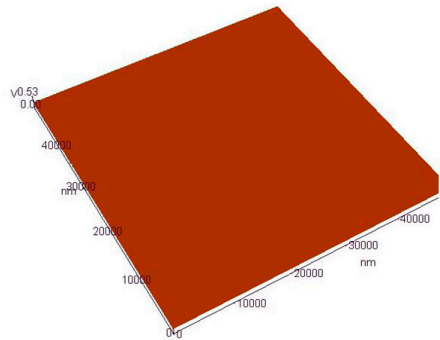

(c)

Figure 9. AFM topographies of $\mathrm{Cr}-\mathrm{Ni}$ coatings with different mass ratios of $\mathrm{Cr}$ and $\mathrm{Ni}$.(a) AFM topography of $17 \% \mathrm{Cr}-83 \% \mathrm{Ni}$ coating; (b) AFM topography of $20 \% \mathrm{Cr}-80 \% \mathrm{Ni}$ coating; (c) AFM topography of $24 \% \mathrm{Cr}-76 \% \mathrm{Ni}$ coating. 
Table 2. Surface roughness of $\mathrm{Cr}-\mathrm{Ni}$ coatings with different mass ratios of $\mathrm{Cr}$ and $\mathrm{Ni}$.

\begin{tabular}{lccccc}
\hline Coating Kinds & $\begin{array}{c}\text { Average Roughness } \\
S_{\mathbf{a}} / \mathbf{n m}\end{array}$ & $\begin{array}{c}\text { Root mean Square } \\
S_{\mathbf{q}} / \mathbf{n m}\end{array}$ & $\begin{array}{c}\text { Surface Skewness } \\
S_{\text {sk }}\end{array}$ & $\begin{array}{c}\text { Surface kurtosis } \\
S_{\text {ku }}\end{array}$ & $\begin{array}{c}\text { Ten Point Height } \\
S_{\mathbf{z}} / \mathbf{n m}\end{array}$ \\
\hline $17 \% \mathrm{Cr}-83 \% \mathrm{Ni}$ & 3.96 & 6.82 & -2.18 & 24.80 & 126 \\
$20 \% \mathrm{Cr}-80 \% \mathrm{Ni}$ & 4.97 & 9.55 & 3.62 & 34.30 & 166 \\
$24 \% \mathrm{Cr}-76 \% \mathrm{Ni}$ & 4.07 & 7.44 & -3.35 & 32.1 & 131 \\
\hline
\end{tabular}

\subsection{XRD Analysis of $\mathrm{Cr}-\mathrm{Ni}$ Coatings}

The XRD patterns of $\mathrm{Cr}-\mathrm{Ni}$ coatings with different mass ratios are shown in Figure 10. The phases of $17 \% \mathrm{Cr}-83 \%, 20 \% \mathrm{Cr}-80 \% \mathrm{Ni}$ and $24 \% \mathrm{Cr}-76 \% \mathrm{Ni}$ coating were composed of $\mathrm{Ni}-\mathrm{Cr}+\mathrm{Ni}+\mathrm{Cr}$, $\mathrm{Ni}_{0.11} \mathrm{Cr}_{0.19}+\mathrm{Ni}_{3} \mathrm{C}_{0.5}+\mathrm{Ni}+\mathrm{Cr}$, and $\mathrm{Ni}_{3} \mathrm{C}_{0.15}+\mathrm{Ni}+\mathrm{Cr}$, respectively, indicating that there are $\mathrm{Cr}+\mathrm{Ni}$ single-phases and their compounds in the $\mathrm{Ni} \mathrm{Cr}-\mathrm{Ni}$ coatings, which were at a different stoichiometry. This was because there were different mass ratios of $\mathrm{Cr}$ and $\mathrm{Ni}$ in the $\mathrm{Cr}-\mathrm{Ni}$ coatings; the $\mathrm{Ni}$ was not only reacted with the $\mathrm{Cr}$ to form the above compounds of $\mathrm{Ni}-\mathrm{Cr}$ and $\mathrm{Ni}_{0.11} \mathrm{Cr}_{0.19}$, but also easily reacted with the $\mathrm{C}$ in the air to form the $\mathrm{Ni}$ carbides of $\mathrm{Ni}_{3} \mathrm{C}_{0.5}$ and $\mathrm{Ni}_{3} \mathrm{C}_{0.15}$.

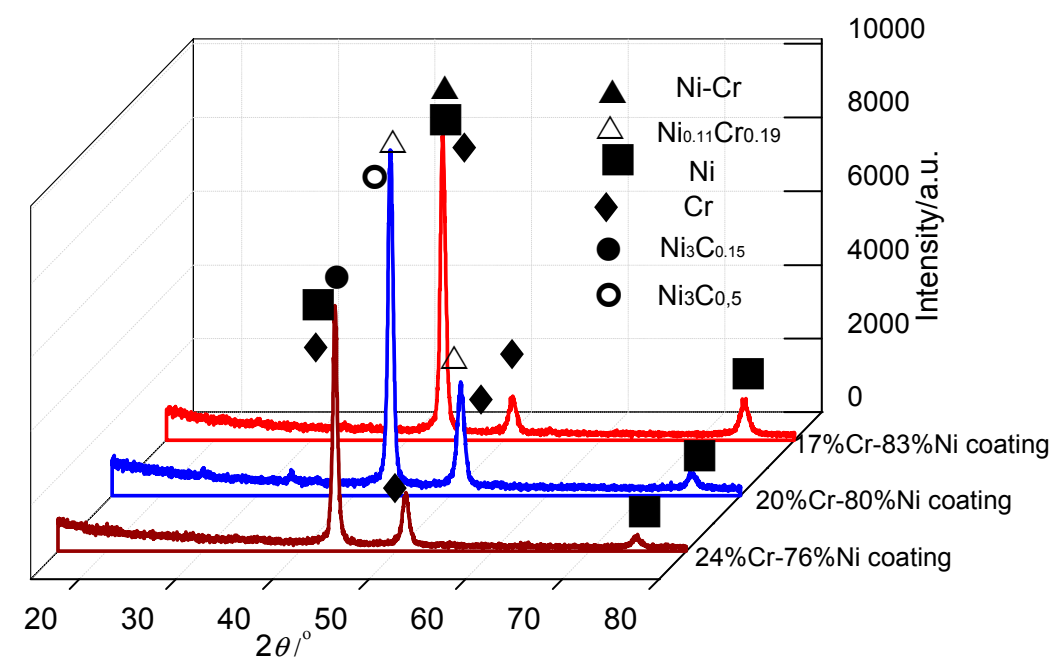

Figure 10. XRD patterns of $\mathrm{Cr}-\mathrm{Ni}$ coatings with different mass ratios of $\mathrm{Cr}$ and $\mathrm{Ni}$.

\subsection{Friction and Wear Performances}

\subsubsection{Coefficients of Friction}

The relationships between the coefficients of friction (COFs) of $\mathrm{Cr}-\mathrm{Ni}$ coatings with different ratios of $\mathrm{Cr}$ and $\mathrm{Ni}$ and the wear time are shown in Figure 11 . The average $\mathrm{COF}$ of $17 \% \mathrm{Cr}-83 \% \mathrm{Ni}, 20 \%$ $\mathrm{Cr}-80 \% \mathrm{Ni}$ and $24 \% \mathrm{Cr}-76 \% \mathrm{Ni}$ coating was $1.10,0.33$, and 0.87 , respectively. The wear process was divided into running-in period and stable wear period, there was no wear failure period. The average COF of $17 \% \mathrm{Cr}-83 \% \mathrm{Ni}$ coating was 0.93 in the running-in period (0-10 $\mathrm{min}$ ), which increased rapidly from 0.50 to 1.03 in the time range of $0-3 \mathrm{~min}$ and then slowly increased to 1.19 at $10 \mathrm{~min}$. The COF of $20 \% \mathrm{Cr}-80 \% \mathrm{Ni}$ coating increased from 0.27 to 0.31 in the running-in period $(0-0.5 \mathrm{~min})$, the average COF was 0.28 . When entering into the stable wear period $(0.5-30 \mathrm{~min})$ with no obvious fluctuation, the average COF was 0.33 . The average COF of $24 \% \mathrm{Cr}-76 \% \mathrm{Ni}$ coating increased rapidly from 0.32 to 0.87 in the running-in period ( $0-5 \mathrm{~min})$, which were obviously fluctuating, and its average COF was 0.33. The average COF was 0.92 in the stable wear period (5-30 min); in the first stable wear period (5-21.25 min), the average COF was 0.94 , and then the COF was reduced from 0.91 to 0.75 at 21.25-21.30 $\mathrm{min}$. In the second stable wear period (21.3-30 $\mathrm{min})$, the average COF dropped to 0.85 . From the above analyses, it can be seen that the $20 \% \mathrm{Cr}-80 \% \mathrm{Ni}$ coating had a lower COF, which was three-times lower than $17 \% \mathrm{Cr}-83 \% \mathrm{Ni}$ and $24 \% \mathrm{Cr}-76 \% \mathrm{Ni}$ coatings. In addition, the plastic deformation at the 
concavo-convex joint was large, which led to higher COF and instability [20]. In addition, for the $\mathrm{Cr}-\mathrm{Ni}$ coatings the oxidation reaction occurred at $600{ }^{\circ} \mathrm{C}$, resulting in the oxides of $\mathrm{NiO}$ and $\mathrm{Cr}_{2} \mathrm{O}_{3}[21$,22], i.e.,

$$
\begin{gathered}
2 \mathrm{Ni}+\mathrm{O}_{2}=2 \mathrm{NiO} \\
4 \mathrm{Cr}+3 \mathrm{O}_{2}=2 \mathrm{Cr}_{2} \mathrm{O}_{3}
\end{gathered}
$$

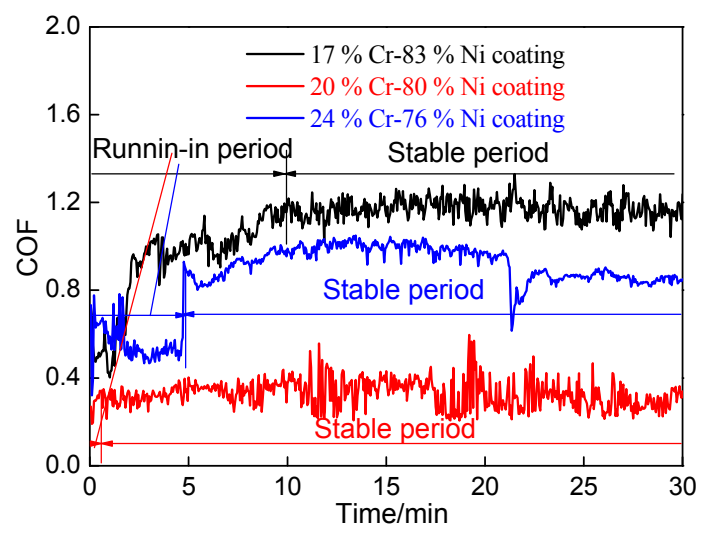

Figure 11. COFs of $\mathrm{Cr}-\mathrm{Ni}$ coatings vs wear time.

When the above oxides were formed, the debris was generated on the worn track, causing the COFs of $\mathrm{Cr}-\mathrm{Ni}$ coatings to oscillate [23]. Under the same oxidation conditions, the $\mathrm{Cr}_{2} \mathrm{O}_{3}$ in Equation (2) was formed prior to the $\mathrm{NiO}$ in Equation (1), this was because the Gibbs free energy of $\mathrm{Cr}_{2} \mathrm{O}_{3}$ was lower than that of $\mathrm{NiO}$ [24]. Therefore, the oxide debris of $24 \% \mathrm{Cr}-76 \% \mathrm{Ni}$ coating was the most, and it had the most obvious fluctuation.

\subsubsection{Profiles of Worn Tracks}

The overall profile of worn track on the $17 \% \mathrm{Cr}-83 \% \mathrm{Ni}$ coating is shown in Figure 12a. The measured position of worn track is shown in Figure 12b, and the profile of worn track is shown in Figure 12c. The wear width and wear depth were 840 and $16.3 \mu \mathrm{m}$, respectively. After calculation, the wear area and wear volume were $6.493 \times 10^{-3} \mathrm{~mm}^{2}$, and $40.797 \times 10^{-3} \mathrm{~mm}^{3}$, respectively, and the corresponding wear rate was $4.533 \times 10^{-6} \mathrm{~mm}^{3} \cdot \mathrm{N}^{-1} \cdot \mathrm{s}^{-1}$.

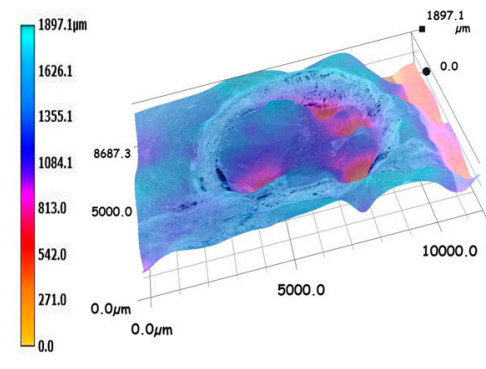

(a)

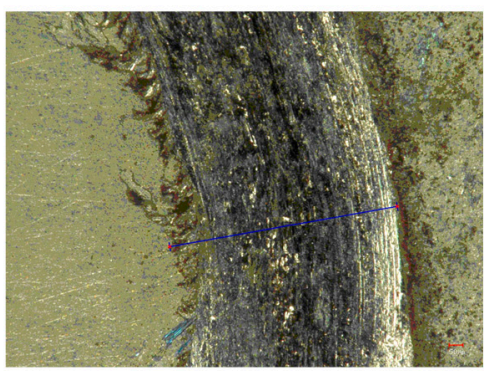

(b)

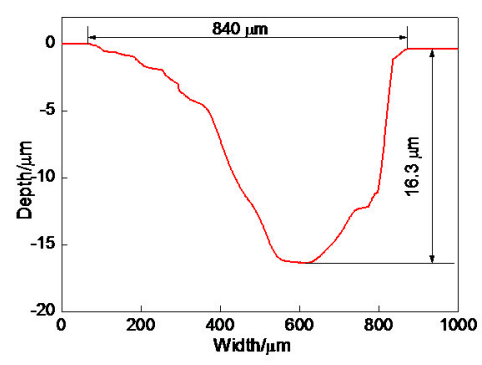

(c)

Figure 12. Profile of worn track on $17 \%$ Cr- $83 \%$ Ni coating. (a) Overall profile of worn track; (b) Measured position of worn track; (c) Profile of worn track.

The overall profile of worn track on the $20 \% \mathrm{Cr}-80 \% \mathrm{Ni}$ coating is shown in Figure $13 \mathrm{a}$. The measured position of worn track is shown in Figure 13b, and the profile of worn track is shown in Figure 13c. The wear width and wear depth of worn track were 744 and $18 \mu \mathrm{m}$, respectively. 
After calculation, the wear area and wear volume were $7.783 \times 10^{-3} \mathrm{~mm}^{2}$ and $48.902 \times 10^{-3} \mathrm{~mm}^{3}$, respectively, and the corresponding wear rate was $5.433 \times 10^{-6} \mathrm{~mm}^{3} \cdot \mathrm{N}^{-1} \cdot \mathrm{s}^{-1}$.

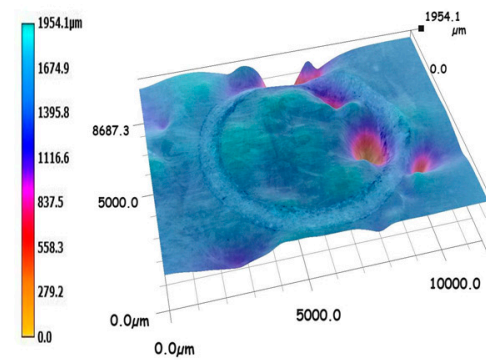

(a)

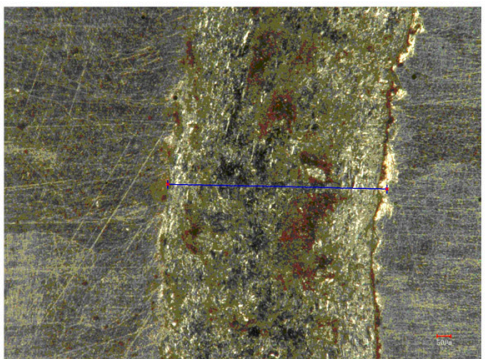

(b)

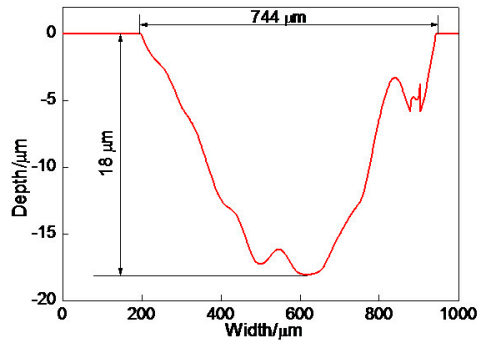

(c)

Figure 13. Profile of worn track on $20 \% \mathrm{Cr}-80 \%$ Ni coating. (a) Overall profile of worn track; (b) Measured position of worn track; (c) Profile of worn track.

The overall profile of worn track on the $24 \% \mathrm{Cr}-76 \% \mathrm{Ni}$ coating is shown in Figure $14 \mathrm{a}$. Figure $14 \mathrm{~b}$ shows the measured position of worn track, and the profile of worn track is shown in Figure 14c. The wear width and wear depth were 593 and $7.8 \mu \mathrm{m}$, respectively. After calculation, the wear area and wear volume were $2.523 \times 10^{-3} \mathrm{~mm}^{2}$ and $15.852 \times 10^{-3} \mathrm{~mm}^{3}$, respectively, and the corresponding wear rate was $1.761 \times 10^{-6} \mathrm{~mm}^{3} \cdot \mathrm{N}^{-1} \cdot \mathrm{s}^{-1}$.

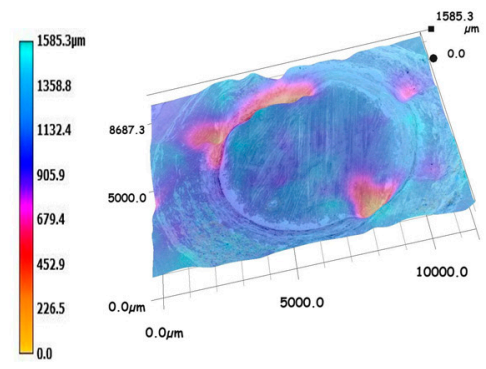

(a)

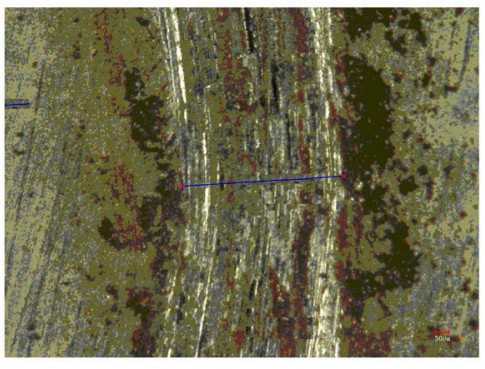

(b)

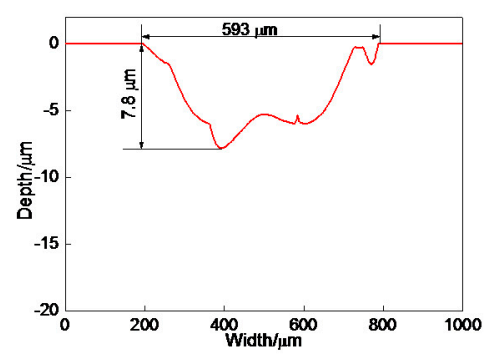

(c)

Figure 14. Profile of worn track on $24 \% \mathrm{Cr}-76 \%$ Ni coating. (a) Overall profile of worn track; (b) Measured position of worn track; (c) Profile of worn track.

According to the above analyses, the wear volumes of $17 \% \mathrm{Cr}-83 \% \mathrm{Ni}$ and $20 \% \mathrm{Cr}-80 \% \mathrm{Ni}$ coatings had no big difference, whereas the wear rate of $24 \% \mathrm{Cr}-76 \% \mathrm{Ni}$ coating was 2-3 times lower than those of $17 \% \mathrm{Cr}-83 \% \mathrm{Ni}$ and $20 \% \mathrm{Cr}-80 \% \mathrm{Ni}$ coatings, indicating that the wear performance of $17 \% \mathrm{Cr}-83 \% \mathrm{Ni}$ coating was the best.

\subsubsection{Worn Morphologies of Friction-pairs}

Figure 15a-c shows the worn morphologies of friction-pairs on the three kinds of $\mathrm{Cr}-\mathrm{Ni}$ coatings at $600{ }^{\circ} \mathrm{C}$. The microhardness values of $17 \% \mathrm{Cr}-83 \% \mathrm{Ni}, 20 \% \mathrm{Cr}-80 \% \mathrm{Ni}, 24 \% \mathrm{Cr}-76 \% \mathrm{Ni}$ coatings were 369.6, 280.3 and $355.7 \mathrm{HV}$, respectively, while the microhardness of ceramic ball was $2200 \mathrm{HV}$, which was obviously higher than the coatings; therefore, the wear mainly occurred in the Cr-Ni coatings, rather than in the ceramic ball. The ceramic balls of friction pairs were not obviously worn; this was because the oxidation temperature of ceramic balls was $1300-1400{ }^{\circ} \mathrm{C}$, while the experimental temperature was $600{ }^{\circ} \mathrm{C}$, which decreased the micro-hardness of Cr-Ni coatings [21], and had no effect on the micro-hardness of ceramic ball. 


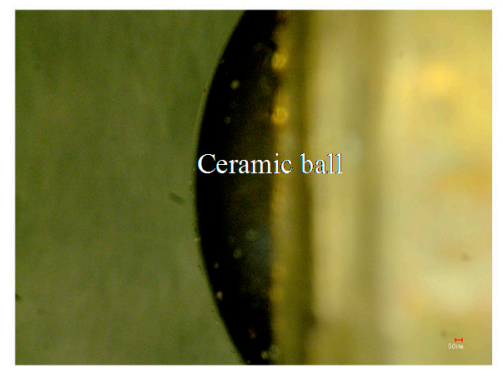

(a)

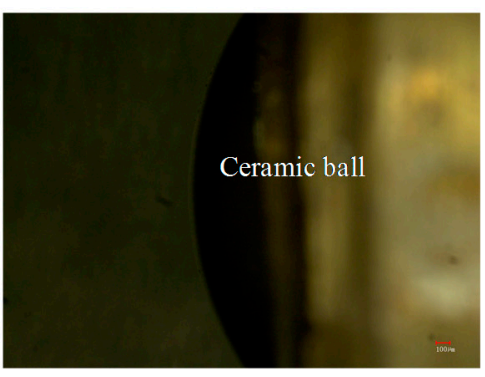

(b)

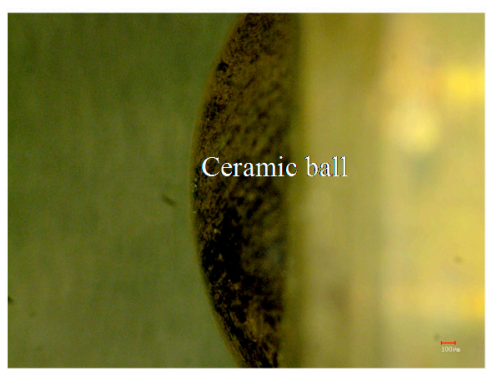

(c)

Figure 15. Worn morphologies of friction-pairs on $\mathrm{Cr}-\mathrm{Ni}$ coatings with different mass ratios of $\mathrm{Cr}$ and Ni. (a) Worn morphology of friction-pair on $17 \% \mathrm{Cr}-83 \% \mathrm{Ni}$ coating; (b) Worn morphology of friction-pair on $20 \% \mathrm{Cr}-80 \% \mathrm{Ni}$ coating; (c) Worn morphology of friction-pair on $24 \% \mathrm{Cr}-76 \%$ Ni coating.

\subsection{Wear Mechanism}

\subsubsection{Plane Scan Analysis of Worn Tracks}

The plane-scanned position of worn track on the $17 \% \mathrm{Cr}-83 \% \mathrm{Ni}$ coating is shown in Figure $16 \mathrm{a}$, which had a litter debris, obvious cracks and flake falling off. Figure $16 \mathrm{~b}$ shows the mass fractions (mass, \%) of plane scan analysis: $\mathrm{Cr}$ 8.86, Ni 86.15, O 5.00. The Pt and Si peaks appeared in the EDS result, among them, the $\mathrm{Pt}$ was the sprayed metal on the $\mathrm{Cr}-\mathrm{Ni}$ coating surface to improve its conduction during the SEM test, and the Si came from the ceramic ball stuck on the worn track. The $\mathrm{Cr}$ and $\mathrm{Ni}$ were the elements of $\mathrm{Cr}-\mathrm{Ni}$ coating, which were uniformly distributed on the worn track, as shown in Figure $16 \mathrm{c}$, d. The $\mathrm{O}$ content accounted for $5.00 \%$ of gross mass fractions, which was the oxidation result of $\mathrm{Cr}-\mathrm{Ni}$ coating at $600{ }^{\circ} \mathrm{C}$; its distribution is shown in Figure 16e.

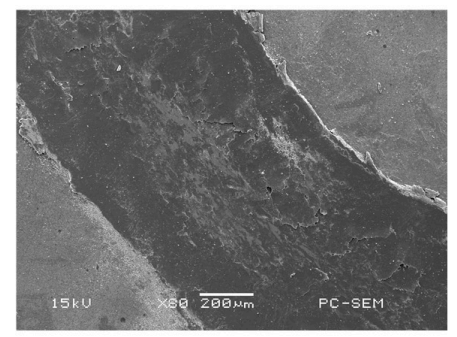

(a)

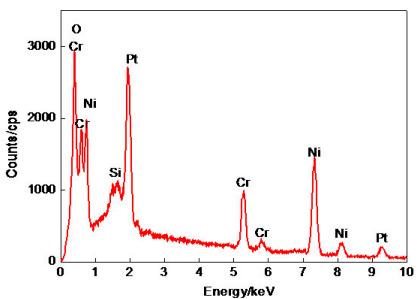

(b)

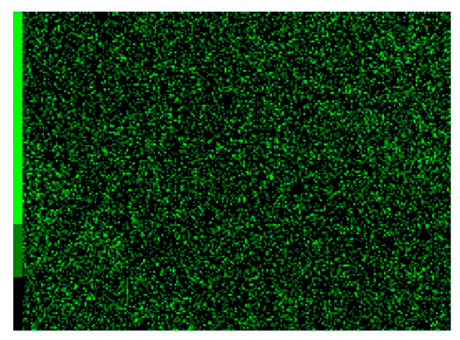

(c)



(d)

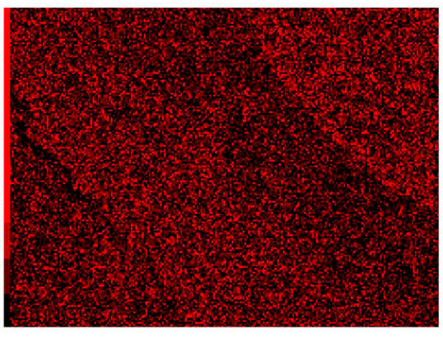

(e)

Figure 16. Plane scan analysis of worn track on $17 \% \mathrm{Cr}-83 \%$ Ni coating. (a) Plane scanned position; (b) Plane scan analysis of worn track on $17 \% \mathrm{Cr}-83 \% \mathrm{Ni}$ coating; (c) Distribution of Cr content; (d) Distribution of Ni content; (e) Distribution of O content. 
The plane scanned position of worn track on the $20 \% \mathrm{Cr}-80 \%$ Ni coating is shown in Figure 17a, in which some debris was accumulated. Figure $17 \mathrm{~b}$ shows the mass fractions (mass, \%) of plane scan analysis: $\mathrm{Cr} 12.58, \mathrm{Ni}$ 82.95, Si 1.06, and O 3.74. The Pt and Si also appeared on the worn track, whose origins were the same as that of $17 \% \mathrm{Cr}-83 \% \mathrm{Ni}$ coating. The $\mathrm{Cr}$ and $\mathrm{Ni}$ accounted for $95.58 \%$ of gross mass fractions, which were the primary compositions of $\mathrm{Cr}-\mathrm{Ni}$ coating, their distributions were uniform with no atoms-rich zones, as shown in Figure 17c,d. The $\mathrm{O}$ accounted for $3.74 \%$ of gross mass fractions, which was uniformly distributed on the worn track with no atom-rich zones, as shown in Figure 17e.

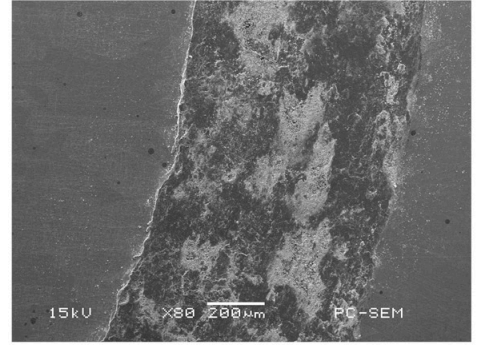

(a)

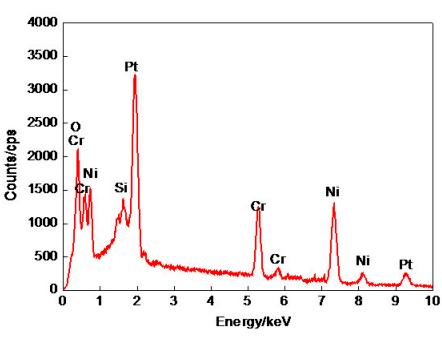

(b)

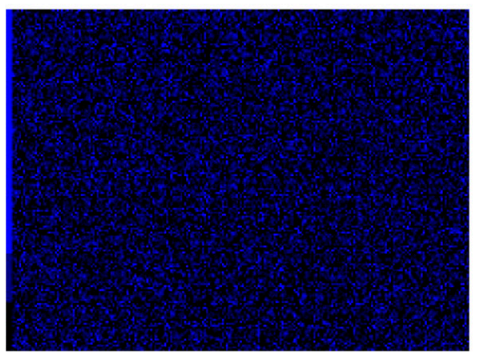

(c)

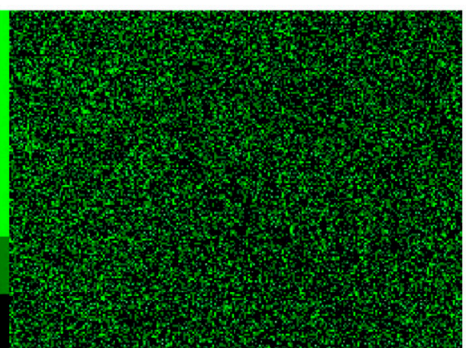

(d)

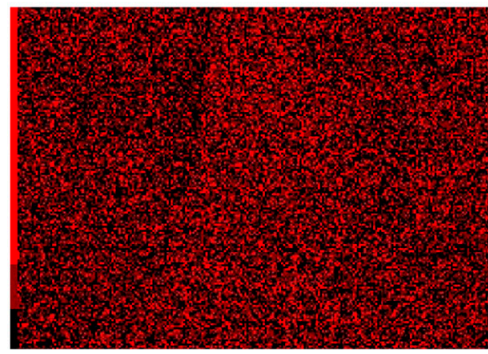

(e)

Figure 17. Plane scan analysis of worn track on $20 \% \mathrm{Cr}-80 \% \mathrm{Ni}$ coating. (a) Plane scanned position; (b) Plane scan analysis of worn track on $20 \% \mathrm{Cr}-80 \%$ Ni coating; (c) Distribution of Cr content; (d) Distribution of Ni content; (e) Distribution of O content.

The plane scanned position of the worn track the of the $24 \% \mathrm{Cr}-76 \% \mathrm{Ni}$ coating is shown in Figure 18a, in which much debris was accumulated. Figure 18 (b) shows the mass fractions (mass, \%) of plane scan analysis of $\mathrm{Cr} 13.32, \mathrm{Ni} 81.74$, Si 1.02, and O 4.84. The Pt was the result of sprayed metal during the SEM test, while the Si was the Si of ceramic ball sticking on the worn track. The $\mathrm{Cr}$ and $\mathrm{Ni}$ were also uniformly distributed on the worn track, as shown in Figure 18c,d. The O accounted for $4.845 \%$ of gross mass fractions, whose distribution is shown in Figure 18e.

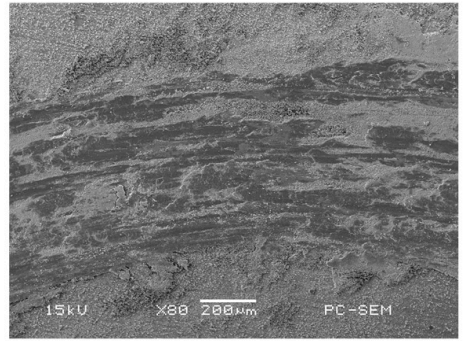

(a)

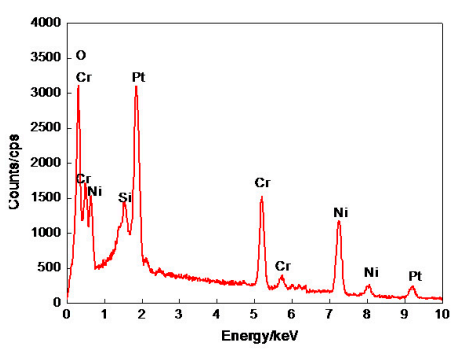

(b)

Figure 18. Cont. 


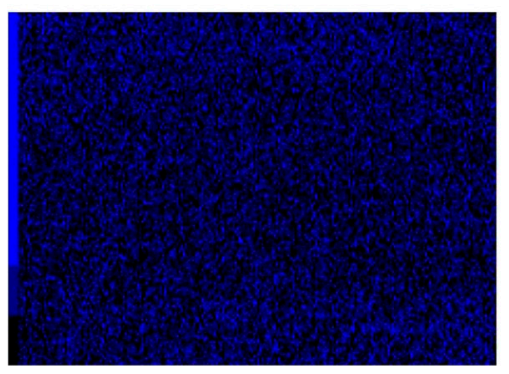

(c)

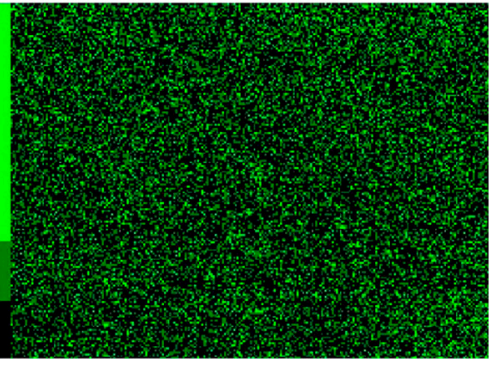

(d)

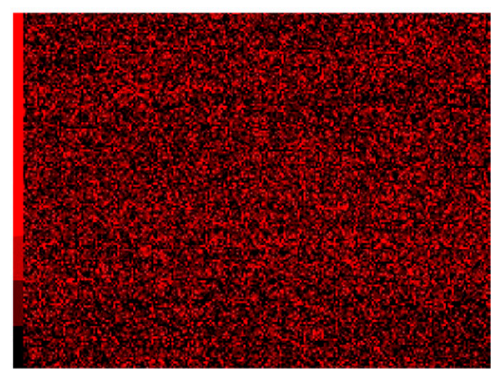

(e)

Figure 18. Plane scan analysis of worn track on $24 \% \mathrm{Cr}-76 \% \mathrm{Ni}$ coating. (a) Plane scanned position; (b) Plane scan analysis of worn track on $24 \% \mathrm{Cr}-76 \%$ Ni coating; (c) Distribution of Cr content; (d) Distribution of Ni content; (e) Distribution of O content.

Compared with the EDS results in Figures $16 \mathrm{~b}, 17 \mathrm{~b}$ and $18 \mathrm{~b}$ and Figures $3 \mathrm{a}, 4 \mathrm{~b}$ and $5 \mathrm{~b}$, the $\mathrm{Cr}-\mathrm{Ni}$ coatings underwent an oxidation reaction at $600{ }^{\circ} \mathrm{C}$, resulting in the oxides of $\mathrm{NiO}$ and $\mathrm{Cr}_{2} \mathrm{O}_{3}$ [21,22], i.e., most of the debris which was generated during wear remained in the form of loose particles, forming stick-slip friction [23]. When the $\mathrm{Ni}$ was alloyed with the $\mathrm{Cr}$ at sufficiently high concentrations, the $\mathrm{Cr}$ was selectively oxidized and the oxidation resistance increased by the $\mathrm{Cr}_{2} \mathrm{O}_{3}$ oxide below $800{ }^{\circ} \mathrm{C}$ [22] The oxidation of $\mathrm{Cr}$ in the $\mathrm{Cr}-\mathrm{Ni}$ coating was depended on the concentration of $\mathrm{Cr}$ and the diffusion rate. When the mass fraction of $\mathrm{Cr}$ was greater than $20 \%$ [22], the diffusion rate increased with the $\mathrm{Cr}$ content increasing. The mass fractions of $\mathrm{Cr}$ in the $20 \% \mathrm{Cr}-80 \% \mathrm{Ni}$ and $24 \% \mathrm{Cr}-76 \% \mathrm{Ni}$ coatings were greater than $20 \%$; therefore, their oxidation resistance was better than the $17 \% \mathrm{Cr}-83 \% \mathrm{Ni}$ coating.

\subsubsection{Worn Morphologies}

In a case of the $17 \% \mathrm{Cr}-83 \% \mathrm{Ni}$ coating, the wear mechanism was adhesive wear, as shown in Figure 19a. There were different scratches and some broken debris on the worn track. The long and deep cracks were clear, as shown in Figure 19b. Although the debris was less in the wear test, the Cr-Ni coating had a spalling trend, as shown in Figure 19c.

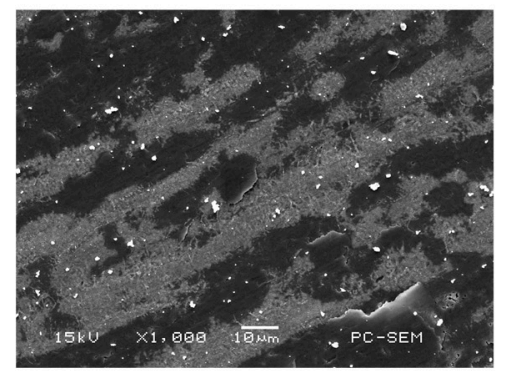

(a)

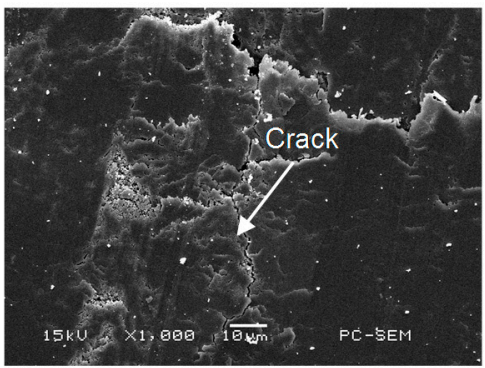

(b)

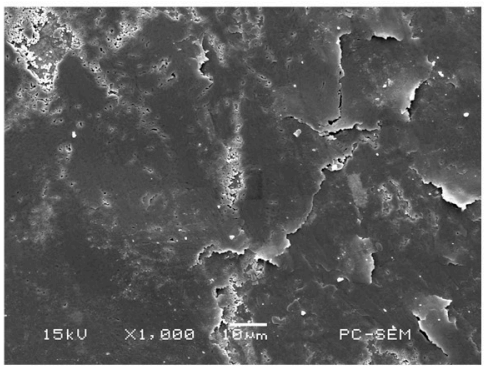

(c)

Figure 19. Morphologies of worn track on $17 \%$ Cr- $83 \%$ Ni coating. (a) Adhesive wear; (b) Crack; (c) Spalling off.

There were some furrows on the $20 \% \mathrm{Cr}-80 \%$ Ni coating; the wear mechanism was adhesive wear as shown in Figure 20a. The fine lattice-like cracks were formed on the worn track, as shown in Figure 20b. Compared with those in Figure 19b, the cracks were much finer and lighter. The large particles were spalled and accumulated, as shown in Figure 20c. 


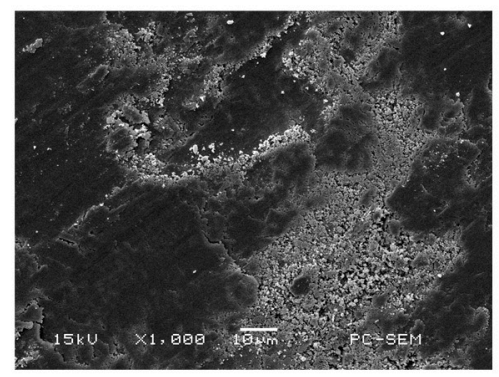

(a)

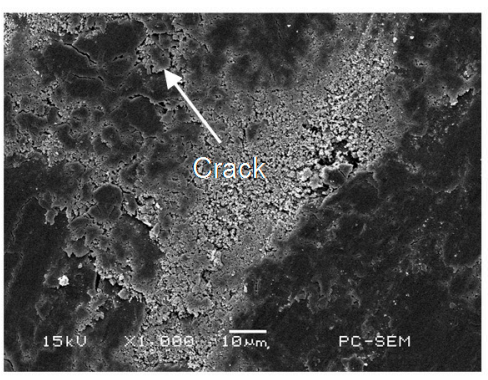

(b)

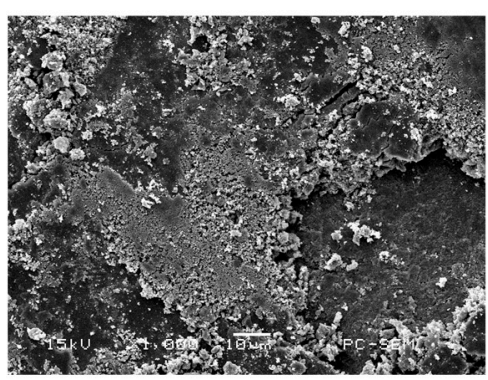

(c)

Figure 20. Morphologies of worn track on $20 \%$ Cr- $80 \%$ Ni coating. (a) Adhesive wear; (b) Crack; (c) Spalling off.

The wear mechanism of $24 \% \mathrm{Cr}-76 \% \mathrm{Ni}$ coating was oxidative wear and adhesive wear, as shown in Figure 21a. The smooth regions (tribo-oxide layer) and the delaminated regions were found on the worn track, which was the typical characteristic of oxidative wear [25], as shown in Figure 21 b. There was a large amount of deposits and large debris particles, which were mainly from the peeling of oxides when they were worn down [23]. Although the debris was much, no cracks were generated, as shown in Figure 21c, indicating that the $24 \% \mathrm{Cr}-76 \% \mathrm{Ni}$ coating was not obviously damaged.

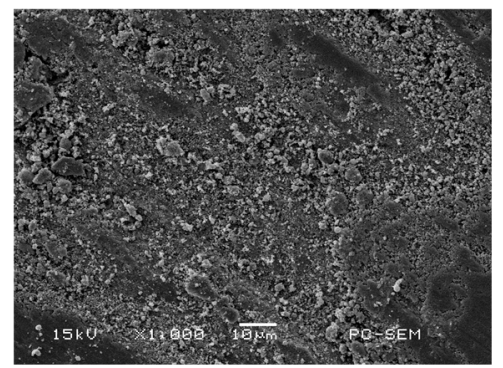

(a)

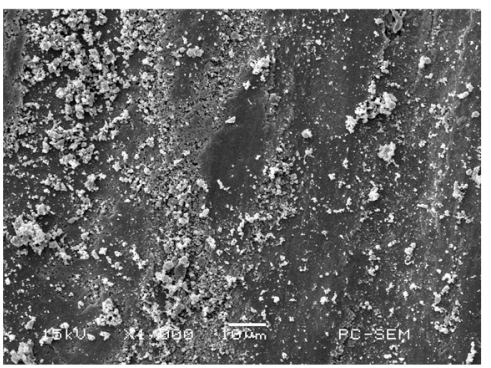

(b)

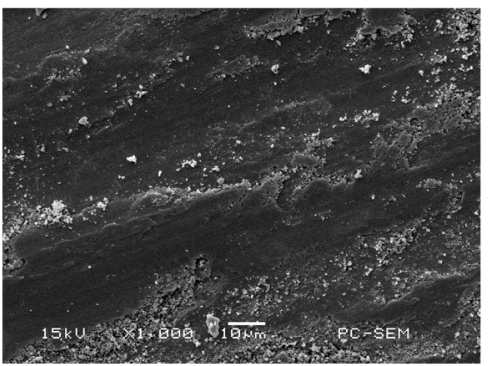

(c)

Figure 21. Morphologies of worn track on $24 \%$ Cr-76\% Ni coating. (a) Adhesive wear; (b) Crack; (c) Spalling off.

When the friction pair was contacted with the $\mathrm{Cr}-\mathrm{Ni}$ coating, the wear first occurred on a few independent asperities. Under the wear load, the local pressure of the asperity exceeded the yield pressure of $\mathrm{Cr}-\mathrm{Ni}$ coating; plastic deformation occurred, so that the adhesion phenomenon appeared on the $\mathrm{Cr}-\mathrm{Ni}$ coating surface. The relative movement led to cutting and breaking, the shedding of $\mathrm{Cr}-\mathrm{Ni}$ coating became debris, and the adhesive-shear-transfer-re-adhesion phenomenon was continuously carried out to form adhesive wear, which was the wear process of $17 \% \mathrm{Cr}-83 \% \mathrm{Ni}$ coating. The wear test results showed that abrasive wear was apparent at room temperature, whereas adhesive wear was dominant at elevated temperatures [26].

The $24 \%$ Cr-76\% Ni coating first experienced oxidized wear, with a great number of oxide particles appearing on the worn track, which at times were removed and at other times were compacted again, forming adhesion wear. The micro-hardness of $\mathrm{Cr}-\mathrm{Ni}$ coatings decreased at high temperature [27], the fragile oxide film was prone to adhesive wear and debris falling off, in which the wear process existed on the $20 \% \mathrm{Cr}-80 \% \mathrm{Ni}$ coating. The $\mathrm{Cr}-\mathrm{Ni}$ coating was oxidized into the fine-grained $\mathrm{Cr}_{2} \mathrm{O}_{3}$ at $600{ }^{\circ} \mathrm{C}$, reducing the presence of cracks [22]. Therefore, no cracks appeared on the $24 \% \mathrm{Cr}-76 \% \mathrm{Ni}$ coating with high content of $\mathrm{Cr}$. From the above analyses, it can be seen that the $24 \% \mathrm{Cr}-76 \% \mathrm{Ni}$ coating had most debris, but the surface was not significantly damaged. Compared to the wear morphologies and wear rates of the $\mathrm{Cr}-\mathrm{Ni}$ coatings with the different mass ratios of $\mathrm{Cr}$ and $\mathrm{Ni}$, the wear resistance 
of $24 \% \mathrm{Cr}-76 \% \mathrm{Ni}$ coating was the best, indicating that the increasing of $\mathrm{Cr}$ content improved its wear resistance.

\section{Conclusions}

(1) The laser-cladded $\mathrm{Cr}-\mathrm{Ni}$ coatings with different ratios of $\mathrm{Cr}$ and $\mathrm{Ni}$ are composed of $\mathrm{Cr}, \mathrm{Ni}$ and their compound phases, with no obvious defects, which are metallurgically combined with the substrate well.

(2) The average COF of $17 \% \mathrm{Cr}-83 \% \mathrm{Ni}, 20 \% \mathrm{Cr}-80 \% \mathrm{Ni}$ and $24 \% \mathrm{Cr}-76 \% \mathrm{Ni}$ coatings are 1.10 , 0.33 , and 0.87 , respectively; among them, the average COF of $20 \% \mathrm{Cr}-80 \% \mathrm{Ni}$ coating is the smallest, showing higher anti-friction performance.

(3) The wear rate of $17 \% \mathrm{Cr}-83 \% \mathrm{Ni}, 20 \% \mathrm{Cr}-80 \% \mathrm{Ni}$ and $24 \% \mathrm{Cr}-76 \% \mathrm{Ni}$ coatings are $4.533 \times 10^{-6}$, $5.433 \times 10^{-6}$, and $1.761 \times 10^{-6} \mathrm{~N}^{-1} \cdot \mathrm{s}^{-1}$, respectively; among them, the wear rate of $24 \% \mathrm{Cr}-76 \% \mathrm{Ni}$ coating is $2-3$ times smaller than that of $17 \% \mathrm{Cr}-83 \% \mathrm{Ni}$ and $20 \% \mathrm{Cr}-80 \% \mathrm{Ni}$ coatings, showing better wear resistance.

(4) The wear mechanism of $17 \% \mathrm{Cr}-83 \% \mathrm{Ni}$ and $20 \% \mathrm{Cr}-80 \% \mathrm{Ni}$ coatings at $600{ }^{\circ} \mathrm{C}$ is primarily adhesive wear, while that of $24 \% \mathrm{Cr}-76 \% \mathrm{Ni}$ coating is adhesive wear accompanied by oxidative wear. The wear performance of $24 \% \mathrm{Cr}-76 \% \mathrm{Ni}$ coating is better than those of $17 \% \mathrm{Cr}-83 \% \mathrm{Ni}$ and $20 \%$ $\mathrm{Cr}-80 \% \mathrm{Ni}$ coatings, showing that the increase of $\mathrm{Cr}$ content is the main ingredient of improving the wear resistance of $\mathrm{Cr}-\mathrm{Ni}$ coatings.

Acknowledgments: Financial support for this research by the Key Research and Development Project of Jiangsu Province (BE2016052) is gratefully acknowledged.

Author Contributions: Li Jiahong and Kong Dejun conceived and designed the experiments; Li Jiahong performed the experiments; Li Jiahong analysed the data; Li Jiahong and Kong Dejun wrote the paper.

Conflicts of Interest: The authors declare no conflict of interest.

\section{References}

1. Min, Y.G.; Wu, X.C.; Wang, R.; Li, L.; Xu, L.P. Prediction and analysis on oxidation of H13 hot work steel. J. Iron Steel Res. Int. 2006, 13, 44-49. [CrossRef]

2. Li, J.Y.; Chen, Y.L.; Hu, J.H. Mechanism of improvement on strength and toughness of H13 die steel by nitrogen. Mater. Sci. Eng. A 2015, 640, 16-23. [CrossRef]

3. Bailey, N.S.; Katinas, C.; Shin, Y.C. Laser direct deposition of AISI H13 tool steel powder with numerical modeling of solid phase transformation, hardness, and residual stresses. J. Mater. Process. Technol. 2017, 247, 223-233. [CrossRef]

4. Liu, J.H.; Wang, G.X.; Bao, Y.P.; Yang, Y.; Yao, W.; Cui, X.N. Inclusion Variations of hot working die steel H13 in refining process. J. Iron Steel Res. Int. 2012, 19, 1-7. [CrossRef]

5. Tazegul, O.; Dylmishi, V.; Cimenoglu, H. Copper matrix composite coatings produced by cold spraying process for electrical applications. Arch. Civ. Mech. Eng. 2016, 163, 344-350. [CrossRef]

6. Chen, S.; Liang, J.; Liu, C.; Sun, K.; Mazumder, J. Preparation of a novel Ni/Co-based alloy gradient coating on surface of the crystallizer copper alloy by laser. Appl. Surf. Sci. 2011, 258, 1443-1450. [CrossRef]

7. Xu, X.; Mi, G.Y.; Chen, L.; Xiong, L.D.; Jiang, P.; Shao, X.Y.; Wang, C.M. Research on microstructures and properties of Inconel 625 coatings obtained by laser cladding with wire. J. Alloys Compd. 2017, 715, 362-373. [CrossRef]

8. Comesana, R.; Quintero, F.; Lusquinos, F.; Pascual, M.J.; Boutinguiza, M.; Duran, A.; Pou, J. Laser cladding of bioactive glass coatings. Acta Biomater. 2010, 6, 953-961. [CrossRef] [PubMed]

9. Zhou, S.F.; Lei, J.B.; Dai, X.Q.; Guo, J.B.; Gu, Z.J.; Pan, H.B. Comparative study of the structure and wear resistance of $\mathrm{NiCrBSi} / 50 \mathrm{wt} \% \mathrm{WC}$ composite coatings by laser cladding and laser induction hybrid cladding. Int. J. Refract. Met. Hard Mater. 2016, 60, 17-27. [CrossRef]

10. Tao, Y.F.; Li, J.; Lv, Y.H.; Hu, L.F. Effect of heat treatment on residual stress and wear behaviors of the $\mathrm{TiNi} / \mathrm{Ti}_{2} \mathrm{Ni}$ based laser cladding composite coatings. Opt. Laser Technol. 2017, 97, 379-389. [CrossRef] 
11. Lei, J.B.; Shi, C.; Zhou, S.F.; Gu, Z.J.; Zhang, L.C. Enhanced corrosion and wear resistance properties of carbon fiber reinforced Ni-based composite coating by laser cladding. Opt. Laser Technol. 2017, 97, 379-389. [CrossRef]

12. Weng, F.; Yu, H.J.; Chen, C.Z.; Liu, J.L.; Zhao, L.J.; Dai, J.J.; Zhao, Z.H. Effect of process parameters on the microstructure evolution and wear property of the laser cladding coatings on Ti-6Al-4V alloy. J Alloys Compd. 2017, 692, 989-996. [CrossRef]

13. He, A.P.; Zeng, J.M. Direct preparation of low Ni-Cr alloy cast iron from red mud and laterite nickel ore. Mater. Des. 2017, 115, 433-440. [CrossRef]

14. Zhang, P.R.; Liu, Z.Q. On sustainable manufacturing of $\mathrm{Cr}-\mathrm{Ni}$ alloy coatings by laser cladding and high-efficiency turning process chain and consequent corrosion resistance. J. Clean. Prod. 2017, 161, 676-687. [CrossRef]

15. Bala, N.; Singh, H.; Prakash, S. High-temperature oxidation studies of cold-sprayed Ni-20Cr and Ni-50Cr coatings on SAE 213-T22 boiler steel. Appl. Surf. Sci. 2009, 255, 6862-6869. [CrossRef]

16. Zhang, Y.; Peng, X.; Wang, F. Development and oxidation at $800{ }^{\circ} \mathrm{C}$ of a novel electrodeposited $\mathrm{Ni}-\mathrm{Cr}$ nanocomposite film. Mater. Lett. 2004, 58, 1134-1138. [CrossRef]

17. Weng, Z.K.; Wang, A.H.; Wu, X.H.; Wang, Y.Y.; Yang, Z.X. Wear resistance of diode laser-clad Ni/WC composite coatings at different temperatures. Surf. Coat. Technol. 2016, 304, 283-292. [CrossRef]

18. Da Silva, M.R.; Gargarella, P.; Gustmann, T.; Botta Filho, W.J.; Kiminami, C.S.; Eckert, J.; Pauly, S.; Bolfarini, C. Laser surface remelting of a Cu-Al-Ni-Mn shape memory alloy. Mater. Sci. Eng. 2016, A661, 61-67. [CrossRef]

19. Zhou, C.Y.; Zhao, S.S.; Wang, Y.B.; Liu, F.L.; Gao, W.Y.; Lin, X.H. Mitigation of pores generation at overlapping zone during laser cladding. J. Mater. Process. Technol. 2015, 216, 369-374. [CrossRef]

20. Zhao, G.G.; Zhou, Y.B.; Zhang, H.J. Sliding wear behaviors of electrodeposited Ni composite coatings containing micrometer and nanometer Cr particles. Trans. Nonferrous Met. Soc. China 2009, 19, 319-323. [CrossRef]

21. Nath, L.; Saha, G.C. Synthesis and characterization of nanocrystalline $\mathrm{Al}_{2} \mathrm{O}_{3}-\mathrm{Ni}(\mathrm{Cr})$ particles using high-energy mechanical alloying process. Surf. Coat. Technol. 2017, 318, 262-269. [CrossRef]

22. Quan, C.; He, Y.D.; Zhang, J. High temperature oxidation behavior of a novel Ni-Cr binary alloy coating prepared by cathode plasma electrolytic deposition. Surf. Coat. Technol. 2016, 292, 11-19. [CrossRef]

23. Conceição, L.D.; D'Oliveira, A.S.C.M. The effect of oxidation on the tribolayer and sliding wear of a Co-based coating. Surf. Coat. Technol. 2016, 288, 69-78. [CrossRef]

24. Wei, D.B.; Zhang, P.Z.; Yao, Z.J.; Wei, X.F.; Zhou, J.T.; Chen, X.H. Preparation and high-temperature oxidation behavior of plasma $\mathrm{Cr}-\mathrm{Ni}$ alloying on Ti6Al4V alloy based on double glow plasma surface metallurgy technology. Appl. Surf. Sci. 2016, 388, 571-578. [CrossRef]

25. Zhang, Q.Y.; Chen, K.M.; Wang, L.; Cui, X.H.; Wang, S.Q. Characteristics of oxidative wear and oxidative mild wear. Tribol. Int. 2013, 61, 214-223. [CrossRef]

26. Feng, K.; Chen, Y.; Deng, P.S.; Li, Y.Y.; Zhao, H.X.; Lu, F.G.; Li, R.F.; Huang, J.; Li, Z.G. Improved high-temperature hardness and wear resistance of Inconel 625 coatings fabricated by laser cladding. J. Mater. Process. Technol. 2017, 243, 82-91. [CrossRef]

27. Yin, J.; Wang, D.Z.; Meng, L.; Ke, L.D.; Hu, Q.W.; Xiao, Y.Z. High-temperature slide wear of Ni-Cr-Si metal silicide based composite coatings on copper substrate by laser-induction hybrid cladding. Surf. Coat. Technol. 2017, 325, 120-126. [CrossRef]

(C) 2018 by the authors. Licensee MDPI, Basel, Switzerland. This article is an open access article distributed under the terms and conditions of the Creative Commons Attribution (CC BY) license (http:/ / creativecommons.org/licenses/by/4.0/). 